\title{
Apoptosis induced by dithiothreitol in HL-60 cells shows early activation of caspase 3 and is independent of mitochondria
}

\author{
L Tartier ${ }^{1}$, YL McCarey ${ }^{1}$, JE Biaglow ${ }^{3}$, IE Kochevar ${ }^{2}$ and \\ KD Held ${ }^{*, 1}$
}

${ }^{1}$ Laboratory of Molecular and Cellular Radiation Biology, Department of Radiation Oncology, Massachusetts General Hospital, Harvard Medical School, Boston, MA 02114, USA

2 Wellman Laboratories of Photomedicine, Department of Dermatology, Massachusetts General Hospital, Harvard Medical School, Boston, MA 02114 USA

3 Division of Oncology Research, University of Pennsylvania, Philadelphia, PA 19104-6072, USA

* Corresponding author: KD Held, Department of Radiation Oncology, COX 302, Massachusetts General Hospital, Fruit Street, Boston, MA 02114, USA. Tel: 617-726-8161; Fax: 617-724-8320; E-mail: kheld@partners.org

Received 7.2.00; revised 17.4.00; accepted 25.05.00 Edited by CJ Thiele

\begin{abstract}
Previous studies have shown that under certain conditions some thiol-containing compounds can cause apoptosis in a number of different cell lines. Herein, we investigated the apoptotic pathways in HL-60 cells triggered by dithiothreitol (DTT), used as a model thiol compound, and tested the hypothesis that thiols cause apoptosis via production of hydrogen peroxide $\left(\mathrm{H}_{2} \mathrm{O}_{2}\right)$ during thiol oxidation. The results show that, unlike $\mathrm{H}_{2} \mathrm{O}_{2}$, DTT does not induce apoptosis via a mitochondrial pathway. This is demonstrated by theabsence of early cytochrome crelease from mitochondria into the cytosol, the lack of mitochondrial membrane depolarization at early times, and the minor role of caspase 9 in DTT-induced apoptosis. The first caspase activity detectable in DTT-treated cells is caspase 3 , which is increased significantly 1-2 h after the start of DTT treatment. This was shown by following the cleavage of both a natural substrate, DFF-45/ICAD, and a synthetic fluorescent substrate, z-DEVD-AFC. Cleavage of substrates of caspases 2 and 8 , known as initiator caspases, doesnotstartuntil3-4 hafterDTTexposure, wellaftercaspase 3 has become active and at a time when apoptosis is in late stages, as shown by the occurrence of DNA fragmentation to oligonucleosomal-sized pieces. Although oxidizing DTT can produce $\mathrm{H}_{2} \mathrm{O}_{2}$, data presented here indicate that DTT-induced apoptosis is notmediated by production of $\mathrm{H}_{2} \mathrm{O}_{2}$ and occurs via a novel pathway that involves activation of caspase 3 at early stages, prior to activation of the common 'initiator' caspases 2 , 8 and 9. Cell Death and Differentiation (2000) 7, 1002-1010.
\end{abstract}

Keywords: dithiothreitol; apoptosis; caspases; mitochondria; HL-60 cells

\begin{abstract}
Abbreviations: AFC, 7-Amino-4-trifluoromethyl coumarin; CHAPS, 3-[(3-cholamidopropyl)-dimethyl ammoniol]-1-propanesulfonate; CSA, cyclosporine A; DCFH-DA, 2',7'-dichlorofluorescin diacetate; $\mathrm{DiOC}_{6}(3), 3,3^{\prime}$-dihexyloxacarbocyanine iodide; DTT, dithiothreitol; $\mathrm{H}_{2} \mathrm{O}_{2}$, hydrogen peroxide; mClCCP, carbonyl cyanide m-chlorophenyl hydrazone; NAC, N-acetylcysteine; PARP, poly-(ADP-ribose) polymerase; PMSF, phenylmethylsulfonyl fluoride; ROS, reactive oxygen species; TPCK, N-tosyl-Lphenylalanine chloromethyl ketone; TLCK, N-tosyl-Lys-chloromethyl ketone; $\Delta \Psi_{\mathrm{m}}$, mitochondrial trans-membrane potential
\end{abstract}

\section{Introduction}

Thiol-containing compounds are effective radiation protectors and anti-oxidants that decrease cell injury from various oxidative stresses. In contrast to that protective effect, we and others have shown that, under certain circumstances, thiols can cause apoptosis. Our initial studies demonstrated that thiols such as dithiothreitol, cysteine, cysteamine, lipoic acid and WR-1065 cause apoptosis in HL-60 human promyelocytic leukemia cells in a fashion dependent on drug concentration and exposure time. ${ }^{1}$ Studies by others have shown that some of the same thiols, i.e., cysteine, cysteamine and WR-1065, cause apoptosis in mouse hybridoma TB8.3 cells $^{2}$ and that $\mathrm{N}$-acetylcysteine (NAC) causes apoptosis in mouse embryo fibroblasts, but only if the cells are transformed and express wild-type p53. ${ }^{3}$ However, little is known about the pathways involved in thiol-induced apoptosis.

Two general, major pathways for apoptosis have been identified, both requiring active caspase proteins either in the early steps (initiator caspases) or in the later stages (effector caspases) of apoptosis. ${ }^{4-6}$ Caspases are present in cells as inactive zymogens that are activated via action of other proteases, including caspases, into heterotetramers formed from two large and two small subunits. One of the apoptotic pathways is induced through death receptors (such as Fas/CD95, TNF $\alpha$ ) which directly activate caspases $8 / 10$ and subsequently trigger caspase executioners (activation of caspases $1 / 4 / 5$ and then caspases 3/6/7) and cell death. In this pathway, mitochondrial signaling seems to be unnecessary but may contribute to apoptosis at a later time as an amplification mechanism. ${ }^{7-11}$ The second general apoptotic pathway is induced by a variety of stimuli including chemotherapeutic drugs, ionizing radiation, etc. In this case, apoptosis occurs through a mitochondria-dependent mechanism in which one of the key hallmarks is the release into the cytosol of apoptotic activating factors such as cytochrome $c$ and AIF, Apoptosis Inducing Factor. ${ }^{4,5,12-17}$ Studies with cell free systems have shown the ability of cytosolic cytochrome $c$, in interaction with the Apaf-1 and dATP, to process the central initiator caspase 9, then the downstream execu- 
tioners such as caspases 3,6 and $7 .^{18-21}$ In some instances the death receptor/caspase 8 pathway and the mitochondria/caspase 9 pathway seem to be separate pathways until they converge at caspase 3 . However, in other instances there can be crosstalk between the caspase 8 and caspase 9 pathways, e.g., caspase 8 can activate caspase 9 via BID cleavage, ${ }^{8}$ or feedback amplification loops, e.g., caspase 3 can activate caspase 9. ${ }^{22}$ Activated caspases lead to the proteolysis of a number of cellular substrates (including PARP, DNA-PK, lamins, and DFF-45/ICAD). ${ }^{23}$ At least one endonuclease, the CAD/ DFF-40 (Caspase Activated DNase), is known to be activated directly by the caspase pathway. ${ }^{24}$

Thiols are able to act as antioxidants by reacting with reactive oxygen species (ROS: hydrogen peroxide, ${ }^{\circ} \mathrm{OH}$, etc.) at relatively high drug concentrations. However, thiols also can be pro-oxidants producing ROS in vitro, particularly $\mathrm{H}_{2} \mathrm{O}_{2}$ via copper-catalyzed thiol oxidation and - $\mathrm{OH}$ via the Fenton reaction. ${ }^{25,26}$ Several studies have suggested involvement of hydrogen peroxide in thiolinduced cell death in attached cell lines, ${ }^{1,27-30}$ although the role of ROS in thiol-induced apoptosis has not been investigated.

Hence, the goals of the present study are twofold. The first is to investigate the apoptotic pathway(s) triggered by thiols in HL-60 cells by assessing the involvement of specific caspases and mitochondria. Potential mitochondrial involvement is of particular interest because mitochondria have been implicated in apoptosis induction by numerous stimuli, especially oxidants. ${ }^{31,32}$ The second goal is to compare thiol-induced apoptosis with that induced by $\mathrm{H}_{2} \mathrm{O}_{2}$ and determine whether thiols cause apoptosis through production of $\mathrm{H}_{2} \mathrm{O}_{2}$. In these studies we have used the dithiol DTT as a model compound because our previous work has shown that it yields similar results to those obtained using cysteine, cysteamine, lipoic acid and WR1065, yet it is somewhat easier to use because of its slower oxidation rate. ${ }^{1,29}$ Human leukemia HL-60 cells are used in these studies because they are sensitive to a large panel of apoptotic stimuli including anticancer drugs such as etoposide and camptothecin and pro-oxidant agents such as hydrogen peroxide. ${ }^{33,34}$

\section{Results}

\section{Apoptotic DNA fragmentation is induced by both DTT and $\mathrm{H}_{2} \mathrm{O}_{2}$ but on different time scales}

Exposure of HL-60 cells to DTT or $\mathrm{H}_{2} \mathrm{O}_{2}$ led to a timedependent apoptotic cell death as determined by the DNA fragmentation assay (Figure 1A). The 2 mM DTT concentration was used in these experiments as it induces the highest apoptosis level in this cell line (Tartier et al, in preparation). Apoptotic DNA ladders are visualized on agarose gels with ethidium bromide (Figure 1B,C). DNA fragmentation was increased substantially after $2 \mathrm{~h}$ and was maximum at $4-5 \mathrm{~h}$ after treatment with $\mathrm{H}_{2} \mathrm{O}_{2}(100 \mu \mathrm{M})$. With DTT (2 mM), DNA fragmentation starts at $2-3 \mathrm{~h}$ and is maximum at $5-6 \mathrm{~h}$ after the start of DTT exposure. Hence, DTT-induced apoptosis is delayed $1-2 \mathrm{~h}$ relative to that caused by $\mathrm{H}_{2} \mathrm{O}_{2}$. The DNA fragmentation is caused by the reduced form of DTT as treatment with oxidized DTT does not induce DNA fragmentation (data not shown).

\section{DTT-treated cells show a low but prolonged production of intracellular hydrogen peroxide}

DCFH-DA passively diffuses through cell membranes, where the acetate is cleaved off by intracellular esterases to form DCFH. DCFH is commonly used to detect the generation of reactive oxygen intermediates. ${ }^{35,36}$ Results shown in Figure $2 \mathrm{~A}$ indicate that cells treated with $2 \mathrm{mM}$ DTT start to show generation of ROS within $5 \mathrm{~min}$ of the addition of the drug, the ROS generation appears maximal at $15 \mathrm{~min}$, then generation decreases to control, untreated levels by $2 \mathrm{~h}$. By comparison, cells treated with $\mathrm{H}_{2} \mathrm{O}_{2}$ show the maximal DCF fluorescence at the earliest measurable time point, then detectable ROS decrease with time to reach control levels in about $1 \mathrm{~h}$ (Figure 2B). Also, although the $\mathrm{H}_{2} \mathrm{O}_{2}$-treated cells reach the same maximal ROS levels as menadione treated cells, the DTT-treated cells never reach that maximal level of ROS. These data suggest DTT produces ROS in a slower fashion than occurs when a bolus of $\mathrm{H}_{2} \mathrm{O}_{2}$ is added to cells, and are consistent with our earlier data showing that the half-life for DTT oxidation (i.e., production of $\mathrm{H}_{2} \mathrm{O}_{2}$ ) is about $1.3 \mathrm{~h}$ in medium $^{29}$ and slightly less than an hour in the presence of cells (Held et al, unpublished).

\section{DTT-induced apoptotic DNA fragmentation is not prevented by removal of $\mathrm{H}_{2} \mathrm{O}_{2}$ using catalase or pyruvate}

Catalase reacts enzymatically with $\mathrm{H}_{2} \mathrm{O}_{2}$ to produce water, but exogenously added catalase can not penetrate most cell types. Pyruvate reacts rapidly with $\mathrm{H}_{2} \mathrm{O}_{2}$ and can act both intracellularly and extracellularly. ${ }^{37}$ The data in Table 1 show that DTT-induced apoptosis is not prevented by removal of $\mathrm{H}_{2} \mathrm{O}_{2}$ by either catalase or pyruvate, although both agents prevent apoptotic DNA fragmentation caused by $\mathrm{H}_{2} \mathrm{O}_{2}$. Such a result suggests that, even though DTT is capable of generating $\mathrm{H}_{2} \mathrm{O}_{2}$ intracellularly (Figure 2A), the $\mathrm{H}_{2} \mathrm{O}_{2}$ is not responsible for the DTT-induced apoptosis.

\section{Activation of caspase 3 is required for DTT-induced apoptosis}

Processing of the so-called 'executioner' caspase 3 protein into its active form and subsequent cleavage of various substrates by the active caspase 3 is associated with apoptosis induced by a broad range of agents. , $^{6,10}$ Therefore, both caspase processing and caspase activity were measured in DTT-treated cells, the former by Western blot analysis of procaspase cleavage and the later by testing the ability of caspases to cleave natural or synthetic fluorescent peptide substrates.

Caspase 3 cleavage into $19-$ and $17-\mathrm{kDa}$ products is evident after $2 \mathrm{~h}$ DTT-treatment (Figure 3A). The 17- and $11-\mathrm{kDa}$ fragments (the latter not recognized by the 


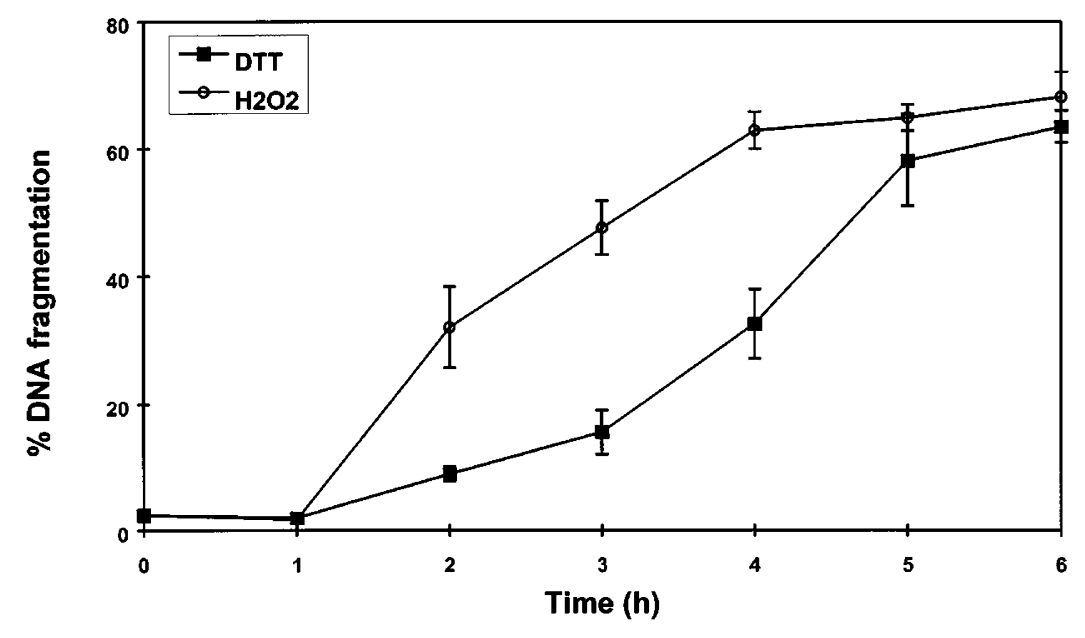

B

\section{C}

\section{$\begin{array}{lllllll}0 & 1 & 2 & 3 & 4 & 5 & 6\end{array}$}

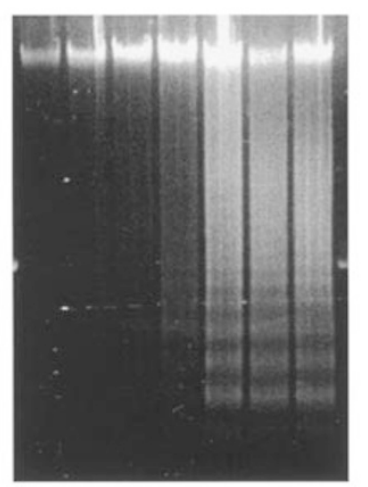

$\begin{array}{llllllll}0 & 1 & 2 & 3 & 4 & 5 & 6 & 1 \mathrm{~kb} \text { ladder }\end{array}$

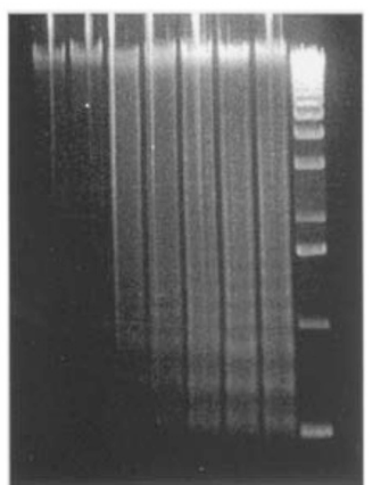

Figure 1 Apoptotic DNA fragmentation in $\mathrm{HL}-60$ cells treated by DTT or $\mathrm{H}_{2} \mathrm{O}_{2}$. (A) HL-60 cells, at a concentration of $5 \times 10^{5}$ cells $/ \mathrm{ml}$, were treated with $2 \mathrm{mM} \mathrm{DTT}$ (西) or $100 \mu \mathrm{M} \mathrm{H}_{2} \mathrm{O}_{2}(\mathrm{O})$ at $37^{\circ} \mathrm{C}$. The drugs were washed off after $2 \mathrm{~h}$ exposure and cells were reincubated at $37^{\circ} \mathrm{C}$ until assay at the indicated time. The percentage of DNA fragmentation was assayed as described in the Materials and Methods. Values are means \pm standard errors (S.E.) of four experiments. (B, C) Agarose gel electrophoresis of DNA extracted from HL-60 cells 0 to $6 \mathrm{~h}$ after treatment with $2 \mathrm{mM} \mathrm{DTT}$ (B) or $100 \mu \mathrm{M} \mathrm{H}_{2} \mathrm{O}_{2}$ (C)

antibody used) are the active subunits of caspase $3^{10,15,38,39}$ The ability of activated caspase 3 to cleave a natural substrate, DFF-45/ICAD (Figure 3B), and the specific synthetic substrate, z-DEVD-AFC (Figure 3C), are also shown. Cleavage of both substrates was detectable $1-2 \mathrm{~h}$ after the start of DTT-treatment, and maximum activity with the fluorescent substrate, about 0.7 nmoles AFC cleaved $/ \mathrm{h} / 10^{6}$ cells, was reached at $4-5 \mathrm{~h}$ (Figure $3 C)$. Cleavage of the natural substrate DFF-45/ICAD is specific for caspase 3-like activity as the addition of zDEVD-cmk, an irreversible inhibitor of caspase 3, prevents its cleavage (Figure 3B). Once cleaved, DFF$45 / I C A D$ releases the protein DFF-40, also known as Caspase Activated DNase (CAD), which is responsible for at least part of the apoptotic DNA fragmentation, ${ }^{24}$ such as that seen in Figure 1.40,41

\section{Caspases 2, 8, 9 and 1 play minor roles, if any, in DTT-induced apoptosis}

Generally, caspase 3 must be processed by other caspases or proteases in order to be activated. Therefore, we next investigated the possible involvement in thiolinduced apoptosis of caspases 2, 8, 9 and 1/4, all of which are known to activate caspase 3 in other circumstances. ${ }^{6,15}$ The effects of irreversible cell permeable caspase inhibitors were studied first. z-DEVD-cmk, zLEHD-fmk and Ac-YVAD-cmk, inhibitors of caspases 3, 9 and $1 / 4$, respectively, were tested, as well as the pancaspase inhibitor z-VAD-fmk (Figure 4). DTT-induced DNA fragmentation is decreased significantly by z-VAD-fmk (3.5fold decrease at $50 \mu \mathrm{M}$; total inhibition with $100 \mu \mathrm{M}-$ data not shown), but is decreased only partially by z-DEVD-cmk 
A

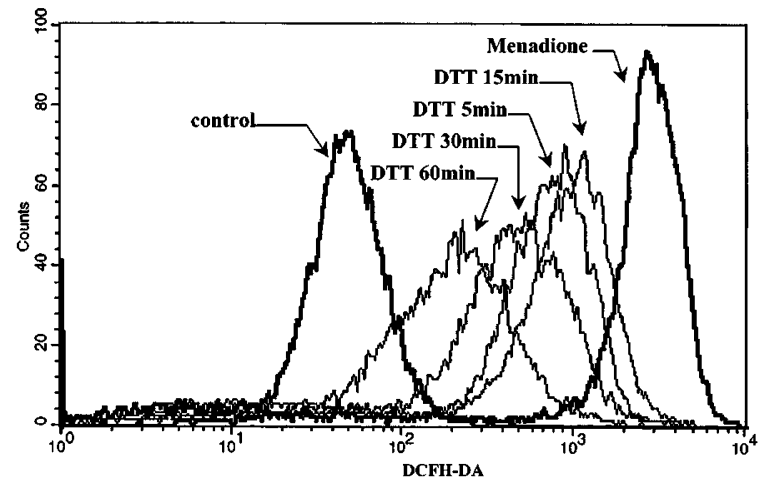

B

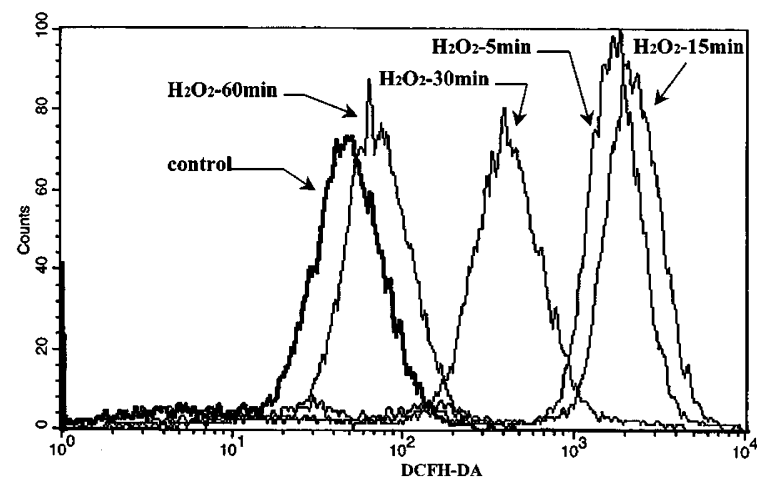

Figure 2 Intracellular hydrogen peroxide measured using DCFH-DA in HL-60 cells treated with $2 \mathrm{mM}$ DTT (A) or $100 \mu \mathrm{M} \mathrm{H}_{2} \mathrm{O}_{2}$ (B) for varying times. The positive control is cells treated with $1 \mathrm{mM}$ menadione for $15 \mathrm{~min}$ (A). DCFH-DA was added to cells $30 \mathrm{~min}$ prior to analysis by flow cytometry. Result shown is typical of three replicate experiments

Table 1 Role of antioxidants in DTT- and $\mathrm{H}_{2} \mathrm{O}_{2}$-induced apoptosis in $\mathrm{HL}-60$ cells

\begin{tabular}{|c|c|c|}
\hline \multirow[b]{2}{*}{ Treatment } & \multicolumn{2}{|c|}{$\%$ DNA fragmentation ${ }^{a}$} \\
\hline & DTT & $\mathrm{H}_{2} \mathrm{O}_{2}$ \\
\hline $\begin{array}{l}\text { Untreated cells } \\
\text { Drug alone } \\
\text { Drug } 1 \mathrm{mg} / \mathrm{ml} \text { catalase } \\
\text { Drug }+10 \mathrm{mM} \text { pyruvate }\end{array}$ & $\begin{array}{c}4.1 \pm 0.1 \\
78.8 \pm 8.7 \\
66.3 \pm 2.0 \\
77.1 \pm 12.2\end{array}$ & $\begin{array}{c}4.1 \pm 0.1 \\
67.8 \pm 0.2 \\
2.6 \\
6.1 \pm 2.2\end{array}$ \\
\hline
\end{tabular}

${ }^{\mathrm{a}}$ Mean \pm S.D. of at least three experiments using at least two different strains of HL-60 cells. ${ }^{\text {bL }}-60$ cells exposed to $2.0 \mathrm{mM}$ DTT for $2 \mathrm{~h}$ or $100 \mu \mathrm{M} \mathrm{H}_{2} \mathrm{O}_{2}$ for $1 \mathrm{~h}$. DNA fragmentation was measured $6 \mathrm{~h}$ after initiation of drug treatment

(twofold decrease at $200 \mu \mathrm{M}$ ). This is consistent with a partial decrease of PARP cleavage by z-DEVD-cmk (data not shown). On the other hand, z-DEVD-cmk prevents cleavage of DFF-45 (Figure 3B). z-VAD-fmk also completely prevents DFF -45 cleavage, but only partially prevents cleavage of PARP (data not shown). The data in Figure 4A, showing only partial protection by z-DEVD$\mathrm{cmk}$, together with the PARP cleavage observations, suggest that a protease in addition to caspase 3 is involved in the thiol-induced pathway. The inhibitors AcYVAD-cmk and z-LEHD-fmk fail to inhibit DNA fragmenta-
A

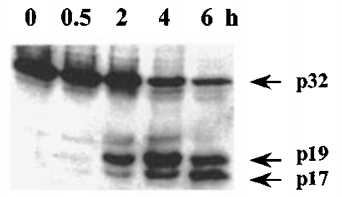

B

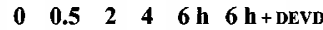

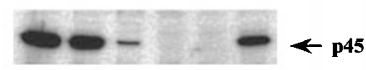

$\mathrm{C}$

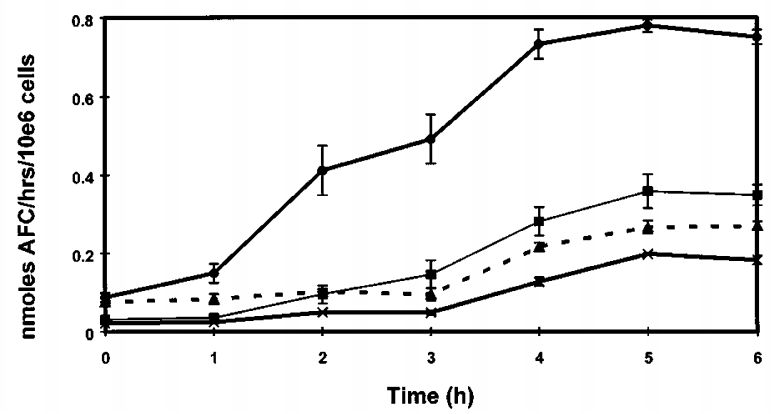

Figure 3 Caspase 3 activity after $2 \mathrm{mM}$ DTT-treatment. (A) Western blot of procaspase 3 (p32) processed to its active peptides $p 19$ and p17. (B) Western blot of DFF-45/ICAD, a natural substrate of caspase 3. The last lane corresponds to $6 \mathrm{~h}$ DTT treatment plus $200 \mu \mathrm{M}$ z-DEVD-cmk, a caspase 3 inhibitor. (C) Caspase activities measured as cleavage of fluorescent peptideAFC: z-DEVD-AFC for caspase $3(\mathbf{0}), z$-VDVAD-AFC for caspase $2(\mathbf{\square})$, z-LEHD-AFC for caspase $9(\mathbf{X})$ and Ac-IETD-AFC for caspase $8(\mathbf{\Lambda})$. Values are means $\pm S$.E. of four experiments. $T=0$ is the cellular extract without DTT treatment. Note that the DTT $(5 \mathrm{mM})$ included in the caspase reaction buffer is not able to activate caspases in the control samples

tion induced by DTT-treatment, indicating caspases 1/4 and 9 are not involved in this pathway. However, a low cleavage activity of caspase 9 toward its synthetic substrate was observed (Figure $3 \mathrm{C}$ ). The cleavage started $4 \mathrm{~h}$ after treatment and reached maximum activity (about 0.1 nmoles AFC $/ \mathrm{h} / 10^{6}$ cells) after $5 \mathrm{~h}$.

In contrast to the significant protection against DTTinduced apoptosis afforded by z-DEVD-cmk (Figure 4A), this caspase 3 inhibitor has no effect on $\mathrm{H}_{2} \mathrm{O}_{2}$-induced apoptosis (Figure 4B). Furthermore, although the caspase 9 inhibitor z-LEHD-fmk has no effect on DTTinduced apoptosis, it decreases $\mathrm{H}_{2} \mathrm{O}_{2}$-induced apoptosis about 25\% (Figure 4B). These observations suggest that, at least in part, the relative importance of different caspases varies for apoptosis induced by DTT and $\mathrm{H}_{2} \mathrm{O}_{2}$.

The roles of caspases 2 and 8 were assessed by observing the cleavage kinetics of their synthetic substrates (Figure 3C). Activity of both caspases increases $3-4 \mathrm{~h}$ after the start of DTT treatment with a maximum activity reached at $5 \mathrm{~h}$ (about 0.2 nmoles AFC/h/10 6 cells). Thus, this increase occurs later than the increase in caspase 3 activity. For caspase 8 , this late activation was confirmed by Western blot, which shows that a significant cleavage of procaspase 8 is seen only after 4 and 6 h DTT-treatment 
A.

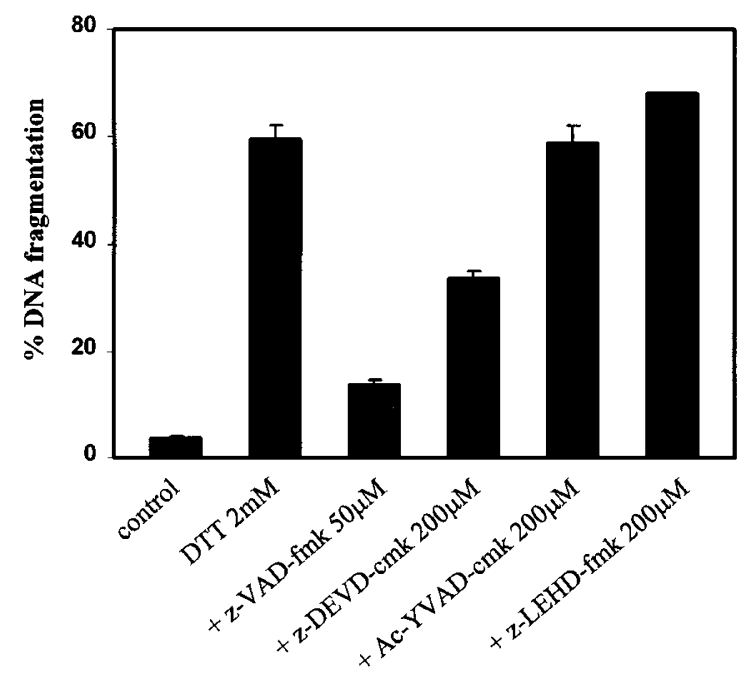

B.

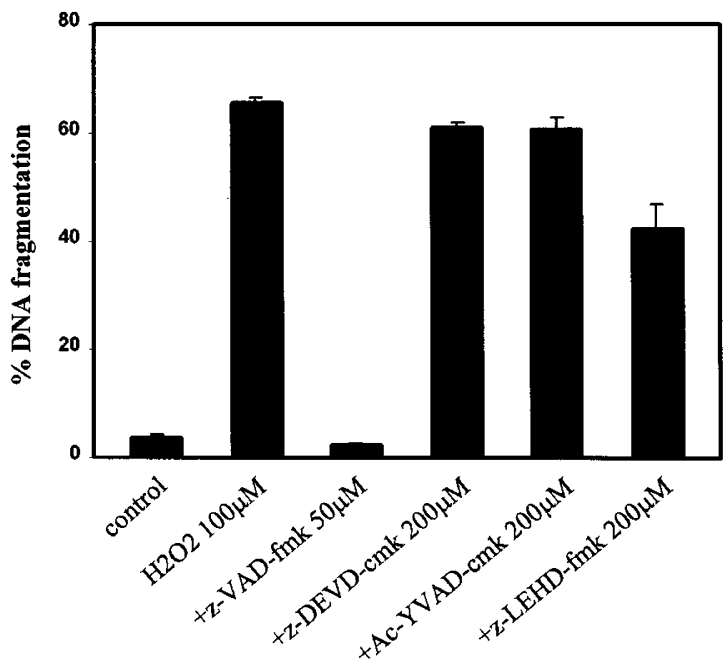

Figure 4 Effect of caspase inhibitors on DTT- and $\mathrm{H}_{2} \mathrm{O}_{2}$ - induced-apoptosis. $\mathrm{HL}-60$ cells were pretreated with the indicated amount of caspase inhibitor for $1 \mathrm{~h}$, and then the cells were treated with $2 \mathrm{mM} \mathrm{DTT}(\mathbf{A})$ or $100 \mu \mathrm{M} \mathrm{H}_{2} \mathrm{O}_{2}$ (B) for $2 \mathrm{~h}$ with assay $4 \mathrm{~h}$ after the removal of the agent. Values are means $\pm \mathrm{S}$.E. of 3-4 experiments. Inhibitors do not have significant effects on cells by themselves (except for z-LEHD-fmk inducing 10\% apoptosis)

(Figure 5A), well after the activation of caspase 3 . The addition of z-DEVD-cmk, an inhibitor selective for caspase 3 , to DTT-treated cells causes a significant decrease of procaspase 8 cleavage (Figure 5B). This finding, together with the slow and small activation of caspase 8 compared with caspase 3 (Figure $3 C$ ), suggests caspase 8 is activated downstream of caspase 3 . In summary, the data suggest caspases 2, 8, 9 and 1/4 are not good candidates to be upstream of caspase 3 , but they are activated later in the thiol-induced apoptotic process as part of a feedback loop to amplify the apoptosis signal. This activation occurs at a time when cells are already undergoing extensive DNA fragmentation (Figure 1A).
A

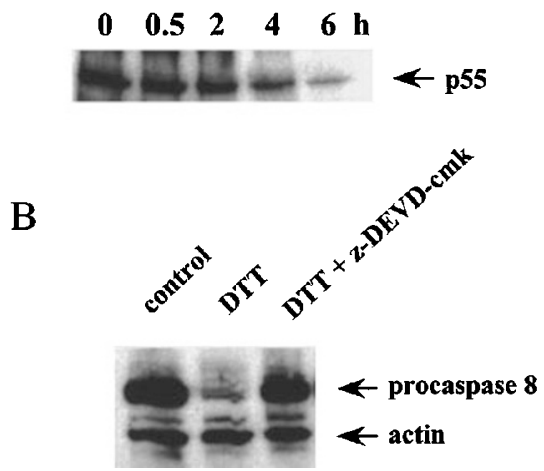

Figure 5 Processing of procaspase-8. (A) Western blot of procaspase-8 (p55) after the indicated times of DTT treatment. Caspase 8 activation is seen as the loss of the band at $55 \mathrm{kDa}$ (pro-form). (B) Effect of an inhibitor of caspase 3 activation on DTT-induced processing of procaspase 8 . Cells were treated with $2 \mathrm{mM}$ DTT $\pm 200 \mu \mathrm{M}$ z-DEVD-cmk for $6 \mathrm{~h}$. No activation of caspase- 8 is seen when caspase 3 is inhibited

\section{DTT-induced apoptosis does not involve mitochondrial signaling}

The opening of the mitochondrial permeability transition (PT) pore appears to be a common event in apoptosis induced by several stimuli triggering oxidative stress, e.g., hydrogen peroxide or t-butylhydroperoxide. ${ }^{32,42}$ It has been shown that when PT is happening, the opening of the pores and the subsequent collapse of the mitochondrial trans-membrane potential $\left(\Delta \Psi_{\mathrm{m}}\right)$ constitute an irreversible step leading to apoptosis. ${ }^{43-45}$ Mitochondrial cytochrome $c$ release may also occur and can either precede the drop in $\Delta \Psi_{\mathrm{m}}{ }^{12,13,20}$ or occur concomitant with the PT pore opening. ${ }^{46,47}$ With DTT treatment, there is a slight and slow decrease of the $\Delta \Psi_{\mathrm{m}}$ (Figure 6), which follows approximately the same time course as that seen for apoptotic DNA fragmentation in this cell line, starting at $3 \mathrm{~h}$ and reaching a maximum $6 \mathrm{~h}$ after treatment (Figure 1A). In contrast, the mitochondrial uncoupler $\mathrm{mCICCP}$ causes a rapid decrease in $\Delta \Psi_{\mathrm{m}}$ to low levels. The small decrease in $\Delta \Psi_{\mathrm{m}}$ caused by DTT may only reflect non-specific changes in mitochondria at relatively late times in the apoptotic pathway. Such an assumption is confirmed by adding cyclosporin A (a ligand of cyclophilin $D$ that is a constituent of the PT pore known for inhibiting its opening), ${ }^{15,48,49}$ to DTT treated-cells. Cyclosporin A has no effect on the slow decrease of $\Delta \Psi_{\mathrm{m}}$ induced by DTT (Figure 6).

Cytochrome $c$ level was also analyzed by Western blot in both cytosolic and mitochondrial fractions of DTT or $\mathrm{H}_{2} \mathrm{O}_{2}$ treated cells. Results with DTT treatment show no significant change in cytochrome $c$ levels in either fraction (Figure 7A), except a slight cytosolic increase of cytochrome $c$ after $6 \mathrm{~h}$. In contrast, HL-60 cells treated with $\mathrm{H}_{2} \mathrm{O}_{2}$ demonstrate rapid accumulation of cytochrome $c$ in the cytosol (starting at $30 \mathrm{~min}$ ) with a parallel decrease in the mitochondrial compartment where the cytochrome $c$ becomes undetectable at $4-6 \mathrm{~h}$ treatment (Figure 7B). No cytochrome oxidase (subunit II) was detected in the 


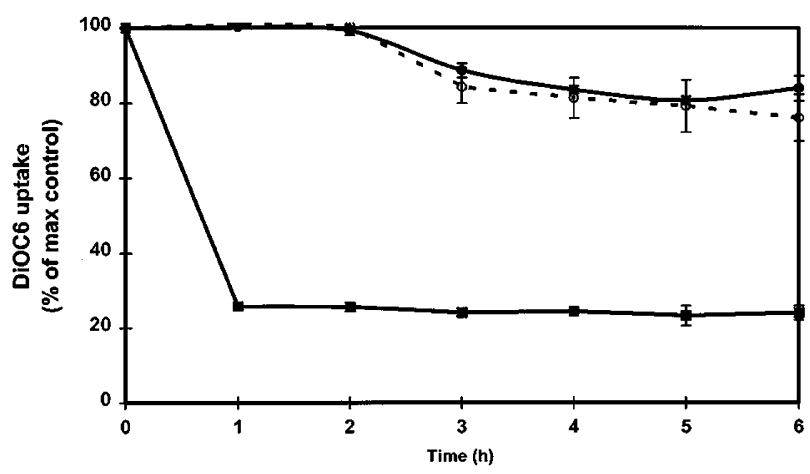

Figure 6 Measurement of mitochondrial trans-membrane potential $\Delta \Psi_{\mathrm{m}}$ Uptake (percentage of maximum control) of the fluorochrome $\mathrm{DiOC}_{6}(3)$ into $\mathrm{HL}-60$ cells treated with $2 \mathrm{mM}$ DTT $(\mathbf{O})$ or $2 \mathrm{mM}$ DTT plus $10 \mu \mathrm{M}$ CSA (O) $100 \mu \mathrm{M} \mathrm{mCICCP}(\boldsymbol{\square})$ was used as a positive control. A decrease of $\mathrm{DiOC}_{6}(3)$ uptake by cells is indicative of disruption of the mitochondrial trans-membrane potential $\Delta \Psi_{\mathrm{m}}$. Values are means \pm S.E. of 3-6 experiments

A

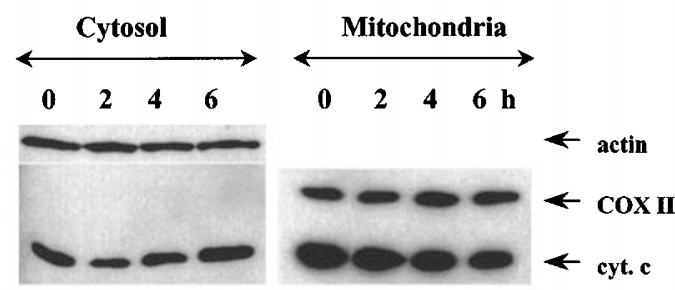

B

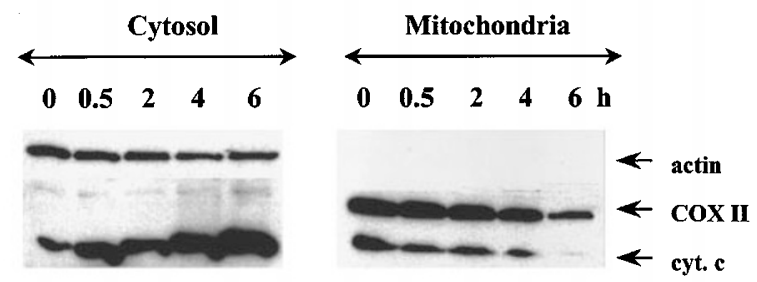

Figure 7 Cytochrome $c$ immunoblotting. Cytochrome $c$ level of both cytosolic and mitochondrial compartments was assessed after different exposure times of $\mathrm{HL}-60$ cells to $2 \mathrm{mM}$ DTT (A) or $100 \mu \mathrm{M} \mathrm{H}_{2} \mathrm{O}_{2}$ (B). Actin protein is used as a loading control in the cytosolic fraction. Cytochrome oxidase subunit II (COX) is used as a mitochondrial loading control and as a mitochondrial marker. Its absence in the cytosolic fraction indicates there is no mitochondrial contamination in that fraction

cytosolic fraction, indicating there was negligible mitochondrial contamination in the preparations. As cytosolic cytochrome $\mathrm{C}$ is indispensible for caspase 9 activation, ${ }^{15,21}$ the late and small cytosolic increase observed here is in accordance with the late activation of caspase 9 seen in the study of cleavage of its fluorescent substrate in DTT-treated cells (Figure 3C). The data imply that mitochondrial signaling does not have a major role in DTT-induced apoptosis, but seems rather to contribute at a later time, perhaps as part of an amplification mechanism. However, the $\mathrm{H}_{2} \mathrm{O}_{2}$ results show that $\mathrm{HL}-60$ cells activate the cytochrome $c$ pathway to apoptosis early in response to at least some stimuli.

\section{Discussion}

Caspase proteins with long prodomains allow caspase aggregation and subsequent autocatalytic activation (such as caspase 2, 8, 10,1/4 and 9), and are commonly believed to act in initial steps of apoptosis. Caspases with short prodomains (such as caspase 3, 6 and 7) commonly act as executioner caspases. ${ }^{6,7,22,50}$ The sequential caspase processing appears to be strongly cell type- and stimulusdependent, although caspase 3 is generally activated late in most systems studied. Strikingly, our data with DTT treatment of HL-60 cells show caspases 2, 8 and 9, usually initiator caspases, are activated later than caspase 3 . Figure $5 B$, which shows that a caspase 3 inhibitor can prevent procaspase 8 activation, emphasizes this result. Additionally, data presented here show that the DTT-induced apoptosis pathway is independent of mitochondrial signaling: there are no early changes in either cytosolic cytochrome c levels or the $\Delta \Psi_{\mathrm{m}}$ (Figures 6 and $7 \mathrm{~A}$ ), and the inability of a caspase 9 inhibitor to inhibit DTT-induced apoptosis (Figure 4A) indicates caspase 9 does not have a key role in this pathway. Thus caspase 3 appears to be an initiator caspase in DTT-treated HL-60 cells, with caspases 2, 8 and 9 activated late and only in a feedback loop, probably due to cleavage by the activated caspase 3 . There are other literature reports describing the ability of caspase 3 to cleave, in vitro and in vivo, upstream caspases, such as caspase 9, as part of a feedback apoptosis amplification loop. . $^{1,23,51,52}$

Although caspase 3 seems to be an initiator rather than an executioner caspase in thiol-treated HL-60 cells, the identity of the initial event triggering procaspase 3 processing is unclear. Studies from Suzuki et $a^{38}$ and Han et $a{ }^{\beta 9}$ suggested the possible involvement of a serine protease in the second stage of the procaspase 3 maturation process (cleavage of the intermediate 19/20-kDa fragment into the active $17-\mathrm{kDa}$ ). Such a pathway could possibly be involved here, but we have been unable to test this hypothesis as all commonly-used serine protease inhibitors we have tested to date, e.g., TPCK and TLCK, cause rapid necrosis (total cell lysis within $1 \mathrm{~h}$ ) in HL-60 cells or have no effect on thiolinduced apoptosis at the very low doses where they do not cause cell killing (data not shown). Other approaches to test for a potential role of serine proteases in this system are being investigated. Alternatively, since the caspase 3 inhibitor is unable to inhibit DTT-induced apoptosis totally, although the pan-caspase inhibitor does (Figure 4A), other as yet unidentified caspases may be involved in DTT-induced activation of caspase 3 .

A number of instances have been reported in the literature of thiol-containing compounds protecting against apoptosis induced, for example, by ionizing radiation, ${ }^{2,53,54}$ etoposide ${ }^{55}$ and TNF- $\alpha .{ }^{56}$ In those studies, the thiols were used under controlled conditions where cell killing by the thiols was minimal. On the other hand, our earlier data, ${ }^{1}$ as well as the data reported herein, have shown clearly, that thiols can cause apoptosis in HL-60 cells. Other examples of thiol-induced apoptosis or thiol enhancement of 
apoptosis have been reported in the literature..$^{2,3,57}$ The paper by Liu et $a{ }^{\beta}$ is particularly interesting. They demonstrated that NAC-induced apoptosis in mouse embryo fibroblasts (MEFs) occurred only if the cells were transformed and wild-type p53; non-transformed MEFs or transformed, p53 null MEFs did not undergo apoptosis when treated with NAC. Those data are consistent with our observations that NAC does not cause apoptosis in HL-60 cells ${ }^{1}$ that are neoplastically transformed and functionally p53 null. On the other hand, in HL-60 cells NAC is not typical of many thiols such as WR-1065, cysteamine, cysteine and lipoic acid that cause apoptosis in a fashion analogous to that shown in this study with $\mathrm{DTT}^{1}$ (Held et al, unpublished data). Clearly, the mode of thiol-induced apoptosis depends on both the specific thiol and the cell type. Hence, it is important to elucidate these various actions when thiols are used as anti-oxidants and antiapoptosis agents.

In previous studies with DTT and other thiols, we had shown that hydrogen peroxide produced by coppercatalyzed thiol oxidation was involved in thiol-induced cell killing measured as loss of clonogenic ability in attached cell lines. ${ }^{1,29,30,58}$ Hence, the original postulate in the current work was that thiol-induced apoptosis in HL-60 cells would also be mediated by hydrogen peroxide production. Data presented in this paper show that hydrogen peroxide is effective in causing apoptosis in HL60 cells (Figure 1), consistent with data of others, ${ }^{59}$ and that DTT can produce hydrogen peroxide in cells (Figure $2 A)$. However, three sets of new data in this paper do not support the hypothesis that DTT-induced apoptosis is mediated by hydrogen peroxide production. First, pyruvate and catalase, which effectively remove hydrogen peroxide, ${ }^{35}$ do not protect against DTT-induced apoptosis (Table 1). Second, Figure 4 shows that the patterns of protection by caspase inhibitors are, at least in part, different for DTTand $\mathrm{H}_{2} \mathrm{O}_{2}$-induced apoptosis. Third, Figure 7 shows that treating HL-60 cells with hydrogen peroxide causes rapid release of cytochrome $c$ from mitochondria into the cytosol, although treating the cells with DTT did not cause any changes in cytochrome $c$. Hence, alternative, non-hydrogen peroxide mediated, mechanisms for activation of apoptosis by thiols in HL-60 cells need to be considered. One potential mechanism is a thiol-mediated reduction of critical disulfides in an enzyme(s) involved in the apoptosis pathway, e.g., a protease that cleaves caspase 3 to its active form. It is unlikely that DTT acts directly on caspase 3 because DTT is commonly included in the reaction buffer used in caspase activity assays and does not cause any activation itself (Figure $3 \mathrm{C}$ ). Clearly, whole cells are required for the initiation of the apoptosis process by DTT. Alternatively, the thiol could be chelating zinc and thus preventing the apoptosis-inhibiting actions of zinccontaining IAP (inhibitor of apoptosis) proteins. ${ }^{60}$

In conclusion, we have demonstrated a novel pathway to apoptosis caused by thiols in HL-60 cells in which caspase 3 , usually a downstream or 'effector' caspase, is activated early, and neither of the common upstream pathways via mitochondria/caspase 9 or death receptor/caspase 8 are involved until the late stages of apoptosis, when DNA fragmentation is well advanced. Although DTT can produce $\mathrm{H}_{2} \mathrm{O}_{2}$, DTT does not appear to be acting via an $\mathrm{H}_{2} \mathrm{O}_{2}$ mediated pathway to cause apoptosis.

\section{Materials and Methods}

\section{Materials}

$\mathrm{HL}-60$ cells were obtained from ATCC (Rockville, MD, USA). $\mathrm{DiOC}_{6}(3)$ and DCFH-DA were from Molecular Probes (Eugene, OR, USA). DTT, CSA, $\mathrm{mCICCP}$, menadione and complete protease inhibitor cocktail were from Sigma (St. Louis, MO, USA). Kits for caspase substrates 3 and 8 were obtained from Clontech (Palo Alto, CA, USA). Substrates for caspase 9 [Z-LEHD-AFC] and 2 [Z-VDVAD-AFC], and inhibitors z-VAD-fmk, z-LEHD-fmk and Ac-YVAD-cmk were obtained from Calbiochem (La Jolla, CA, USA). z-DEVD-cmk was from Bachem Bioscience (King of Prussia, PA, USA).

\section{Cell culture}

Human leukemia HL-60 cells were cultured in RPMI 1640 medium supplemented with penicillin $(100 \mu \mathrm{g} / \mathrm{ml})$, streptomycin (100 units $/ \mathrm{ml})$ and $20 \%$ fetal bovine serum (FBS). The cells were maintain in log phase growth at $37^{\circ} \mathrm{C}$ under a humidified atmosphere of $5 \% \mathrm{CO}_{2}$.

\section{Agarose gel electrophoresis of DNA}

DNA samples were prepared for agarose gel electrophoresis following the procedure of Hopcia et al. ${ }^{61}$ DNA fragments were visualized by ethidium bromide staining.

\section{Flow cytometry analysis of cells by DCFH-DA staining}

In order to determine the presence of intracellular oxidants, HL-60 cells were treated in complete medium at $37^{\circ} \mathrm{C}$ with $2 \mathrm{mM}$ DTT or $100 \mu \mathrm{M} \mathrm{H}_{2} \mathrm{O}_{2}$ for various times. As a positive control, cells were treated with $1 \mathrm{mM}$ menadione for $15 \mathrm{~min}$. DCFH-DA $(10 \mu \mathrm{M})$ was added 30 min prior to analysis by flow cytometry (Epics-Elite flow cytometer). A total of 10000 events were analyzed for each sample. Data were analyzed using CellQuest software and are representative of three replicate experiments.

\section{Western blotting for caspases and DFF-45}

Control and treated cells were lysed in lysis buffer (10 mM HEPES $\mathrm{pH} 7.4,42 \mathrm{mM} \mathrm{KCl}, 5 \mathrm{mM} \mathrm{MgCl} 2,0.1 \mathrm{mM}$ EDTA, $0.1 \mathrm{mM}$ EGTA, $5 \mathrm{mM}$ DTT, $2 \mathrm{mM}$ PMSF, $1 \times$ complete protease inhibitor cocktail) containing $0.5 \%$ CHAPS. Cellular debris were spun down at $14000 \times g$ for $20 \mathrm{~min}$, and the supernatants were used as whole cell protein extracts. Polyclonal Ab anti-caspase 3 (antiserum, Pharmingen, San Diego, CA, USA) was diluted at 1:2000, anti-caspase 8 (clone B9-2, Pharmingen) at $1 \mu \mathrm{g} / \mathrm{ml}$ and polyclonal anti-DFF-45 (C-19, Santa Cruz Biotech) at 1:1000. The appropriate horseradish peroxidase coupled secondary antibody was used, and bound antibodies were revealed with ECL-Plus (Amersham, Arlington, IL, USA).

\section{Preparation of cytosolic and mitochondrial extract for cytochrome $c$ immunoblotting}

Cytosolic and mitochondrial fractions were obtained as described by Han et al. ${ }^{17}$ Thirty $\mu \mathrm{g}$ of cytosolic protein extract or $10 \mu \mathrm{g}$ of 
mitochondrial protein extract mixed with loading buffer were loaded onto each lane of an $8-16 \%$ gradient SDS-polyacrylamide gel (precast gels, Bio-Rad, Hercules, CA, USA), electrophoresed and then blotted to PVDF membrane. Anti-cytochrome $c$ mouse monoclonal antibody $7 \mathrm{H} 82 \mathrm{C} 12$ (Pharmingen) was diluted at 1:5000, anticytochrome oxidase subunit II mouse monoclonal antibody 12C4.F12 (Molecular Probes, Eugene, OR, USA) at 1:2000, and anti-actin goat polyclonal antibody (Santa Cruz Biotech., CA, USA) at $1: 2000$. Bound antibodies were revealed as described previously.

\section{Caspase assay}

Caspase activities were assayed by release of AFC-fluorescent compound from synthetic peptides according to the procedures of the kit manufacturer (Clontech). Approximately $1 \times 10^{6}$ cells were spun at 2000 r.p.m. for $5 \mathrm{~min}$, washed in PBS, and resuspended in $50 \mu \mathrm{l}$ of chilled cell lysis buffer. The cell lysates were centrifuged at 12000 r.p.m. for $3 \mathrm{~min}$, the supernatants were transferred to new tubes, and $50 \mu \mathrm{l}$ of $2 \times$ reaction buffer [ $100 \mathrm{mM}$ HEPES pH 7.2, $0.2 \mathrm{M}$ $\mathrm{NaCl}, 2 \mathrm{mM}$ EDTA, $0.2 \%$ CHAPS, $20 \%$ sucrose] containing $5 \mathrm{mM}$ DTT was added. The reactions were initiated by addition of $50 \mu \mathrm{M}$ substrates-AFC and incubated $1 \mathrm{~h}$ at $37^{\circ} \mathrm{C}$. The fluorescence was read on a Perkin-Elmer LS-5 fluorometer with excitation and emission wavelengths of $400 \mathrm{~nm}$ and $505 \mathrm{~nm}$, respectively.

\section{DNA fragmentation assay for apoptosis}

DNA fragmentation characteristic of apoptosis was measured according to the method of Sellins and Cohen, ${ }^{62}$ with modification. ${ }^{61}$ Cellular DNA was labeled by growth of cells in medium containing $0.02 \mu \mathrm{Ci} / \mathrm{ml}\left[{ }^{14} \mathrm{C}\right]$-thymidine for approximately $24 \mathrm{~h}$, followed by a 'chase' in fresh medium lacking radiolabel for $4 \mathrm{~h}$ before drug treatments. After treatment, cells at a concentration of about $5 \times 10^{5}$ cells/sample were lysed (10 mM Tris, $1 \mathrm{mM} \mathrm{EDTA}$ and $0.2 \%$ Triton $\mathrm{X}-100, \mathrm{pH} 7.5)$. The cell lysates were centrifuged at $13000 \times g$ for $10 \mathrm{~min}$ at $4{ }^{\circ} \mathrm{C}$, and the DNA of the separated pellet and supernatant was hydrolyzed for $20 \mathrm{~min}$ at $90^{\circ} \mathrm{C}$ by the addition of $\mathrm{HCl}$ to a final concentration of $1 \mathrm{~N}$. The samples were mixed with scintillation cocktail (Scintiverse II, Fisher Scientific) and counted in a Packard Tri Carb 4000 series liquid scintillation counter. The percentage of fragmented DNA in each sample was calculated as the amount of DNA in the supernatant divided by the total DNA for that sample (supernatant plus pellet).

\section{Assessment of mitochondrial potential}

Mitochondrial trans-membrane potential $\left(\Delta \Psi_{\mathrm{m}}\right)$ was evaluated using $\mathrm{DiOC}_{6}(3)$, a fluorochrome which incorporates into cells dependent upon their $\Delta \Psi_{\mathrm{m}}$. Cells (at about $5 \times 10^{5} / \mathrm{ml}$ ) were pre-incubated with $60 \mathrm{nM}$ DiOC6(3) for $30 \mathrm{~min}$ at $37^{\circ} \mathrm{C}$ in the dark, then washed once in media and drug added. At appropriate times after drug addition, cells were washed and resuspended in PBS. The fluorescence was measured in PBS on a Perkin-Elmer LS-5 spectrofluorometer (excitation $487 \mathrm{~nm}$, emission $515 \mathrm{~nm}$ ). Control experiments were performed in the presence of $100 \mu \mathrm{M} \mathrm{mCICCP}$, an uncoupling agent that abolishes the $\Delta \Psi_{\mathrm{m}}$.

\section{Acknowledgements}

This work was supported in part by NIH grants CA63997 (to KD Held), CA44982 (to JE Biaglow) and GM30755 (to IE Kochevar) and DOE grant DE-FG07-99ER62874 (to KD Held).

\section{References}

1. Held KD, Sylvester FC, Hopcia KL and Biaglow JE (1996) Role of Fenton chemistry in thiol-induced toxicity and apoptosis. Radiat. Res. 145: 542-553

2. Warters RL, Roberts JC, Wilmore BH and Kelley LL (1997) Modulation of radiation-induced apoptosis by thiolamines. Int. J. Radiat. Biol. 72: 439-448

3. Liu M, Pelling JC, Ju J, Chu E and Brash DE (1998) Antioxidant action via p53mediated apoptosis. Cancer Res. 58: 1723-1729

4. Ashkenazi A and Dixit VM (1998) Death receptors: Signaling and modulation. Science 281: 1305-1308

5. Green DR andReedJC (1998) Mitochondria and apoptosis. Science 281:13091312

6. Thornberry NA and Lazebnik Y (1998) Caspases: Enemies within. Science 281: $1312-1316$

7. Salvesen GS and Dixit VM (1997) Caspases: intracellular signaling by proteolysis. Cell 91: $443-446$

8. Li H, Zhu H, Xu C and Yuan J (1998) Cleavage of BID by Caspase 8 mediates the mitochondrial damage in the Fas pathway of apoptosis. Cell 94: 491-501

9. Vercammen D, Brouchaert G, Denecker G, Van De Craen M, Declercq W, Friers W and Vandenabeele $P$ (1998) Dual signaling of the Fas receptor: initiation of both apoptotic and necrotic cell death pathways. J. Exp. Med. 188: 919-930

10. Ferrari D, Stepczynska A, Los M, Wesselborg S and Schulze-Osthoff K (1998) Differential regulation and ATP requirement for caspase-8 and caspase-3 activation during CD95- and anticancer drug-induced apoptosis. J. Exp. Med. 188: $979-984$

11. Juo P, Kuo CJ, Yuan J and Blemis J (1998) Essential requirement for caspase 8/ FLICE in the initiation of the Fas-induced apoptotic cascade. Curr. Biol. 8: 1001 1008

12. Bossy-WetzelE, NewmeyerDD and GreenDR(1998) Mitochondrial cytochrome c release in apoptosis occurs upstream of DEVD-specific caspase activation and independently of mitochondrial transmembrane depolarization. EMBO J. 17: $37-49$

13. Stridh M, Kimland M, Jones DP, Orrenius S and Hampton MB (1998) Cytochrome $c$ release and caspase activation in hydrogen peroxide- and tributyltin-induced apoptosis. FEBS Lett. 429: 351-355

14. Marchetti P, Castedo M, Susin SA, Zamzami N, Hirsch T, Macho A, Haeffner A, Hirsch F, Geuskens M and Kroemer G (1996) Mitochondrial permeability transition is a central coordinating event of apoptosis. J. Exp. Med. 184: 11551160

15. Slee EA, Harte MT, Kluck RM, Wolf BB, Casiano CA, Newmeyer DD, Wang H-G, Reed JC, Nicholson DW, Alnemri ES, Green DR and Martin SJ (1999) Ordering the cytochrome c-initiated caspase cascade: hierarchical activation of caspases-2, $-3,-6,-7,-8$, and -10 in a caspase 9-dependent manner. J. Cell Biol. 144: 281-292

16. Yang J, Liu X, Bhalla K, Kim CN, Ibrado AM, Cai J, Peng T-I, Jones DP and Wang $X$ (1997) Prevention of apoptosis by Bcl-2: Release of cytochrome c from mitochondria blocked. Science 275: 1129-1132

17. Han Z, Bhalla K, Pantazis P, Hendrickson EA and Wyche JH (1999) Cif(cytochrome $c$ efflux-inducing factor) activity is regulated by $\mathrm{Bcl}-2$ and caspases and correlates with the activation of Bid. Mol. Cell. Biol. 19:1381-1389

18. Liu X, Kim CC, Yang J, Jemmerson R and Wang X (1996) Induction of apoptotic program in cell-free extracts: requirement for dATP and cytochrome c. Cell 86: $147-157$

19. Zou H, Henzel WJ, Liu X, Lutschg A and Wang X (1997) Apaf-1, a human protein homologous to $\mathrm{C}$. elegans CED-4, participates in cytochrome c-dependent activation of caspase-3. Cell 90: 405-413

20. Kluck RM, Bossy-Wetzel E, Green DR and Newmeyer DD (1997) The release of cytochrome c from mitochondria: A primary site for $\mathrm{Bcl}-2$ regulation of apoptosis. Science 275: $1132-1136$

21. Li P, Nijhawan D, Budihardjo I, Srinivasula SM, Ahmad M, Alnemri ES and Wang $X$ (1997) Cytochrome $c$ and dATP-dependent formation of apaf-1/caspase-9 complex initiates an apoptotic protease cascade. Cell 91: 479-489

22. Green D and Kroemer G (1998) The central executioners of apoptosis: caspases or mitochondria? Trends Cell Biol. 8: 267-271

23. Cohen GM (1997) Caspases: the executioners of apoptosis. Biochem. J. 326 $1-16$

24. Enari M, Sakahira H, Yokoyama H, Okawa K, Iwamatsu A and Nagata SA (1998) A caspase-activated DNase that degrades DNA during apoptosis, and its inhibitor ICAD. Nature 391: 43-50 
25. KachurAV, Held KD, Koch CJ and BiaglowJE(1997)Mechanism of production of hydroxyl radicals in the copper-catalyzed oxidation of dithiothreitol. Radiat. Res. 147: $409-415$

26. Biaglow JE, Manevich Y, Uckun F and Held KD (1997) Quantitation of hydroxy radicals produced by radiation and copper-linked oxidation of ascorbate by 2 deoxy-D-ribose method. Free Radic. Biol. Med. 22: 1129-1138

27. Takagi Y, Shikita M, Terasima T and Akaboshi S (1974) Specificity of radioprotective and cytotoxic effects of cysteamine in HeLa S3 cells: Generation of peroxide as the mechanism of paradoxical toxicity. Radiat. Res. 60:292-301

28. Biaglow JE, Issels RD, Gerweck LE, Varnes ME, Jacobson B, Mitchell JB and Russo A (1984) Factors influencing the oxidation of cysteamine and other thiols: Implications for hyperthermic sensitization and radiation protection. Radiat. Res. 100: $298-312$

29. Held KD and Biaglow JE (1993) Role of copper in the oxygen radical-mediated toxicity of the thiol-containing radioprotector dithiothreitol in mammalian cells. Radiat. Res. 134: 375-382

30. Held KD and Biaglow JE (1994) Mechanisms for the oxygen radical-mediated toxicity of various thiol-containing compounds in cultured mammalian cells. Radiat. Res. 139: 15-23

31. Zoratti M and Szabo I (1995) The mitochondrial permeability transition. Biochim. Biophys. Acta 1241: 139-176

32. Chernyak BV (1997) Redox regulation of the mitochondrial permeability transition pore. Bioscience Reports 17: 293-302

33. Schimizu T and Pommier Y (1997) Camptothecin-induced apoptosis in p53-null HL60 cells and their isolated nuclei: effects of the protease inhibitors Z-VAD-fmk and dichloroisocoumarin suggest an involvement of both caspases and serine proteases. Leukemia 11: 1238-1244

34. Yoshida A, Pourquier P and Pommier Y (1998) Purification and characterization of a $\mathrm{Mg}^{2+}$-dependent endonuclease (AN34) from etoposide treated $\mathrm{HL} 60$ cells undergoing apoptosis. Cancer Res. 58: 2576-2582

35. Rothe $G$ and Valet $G$ (1990) Flow cytometric analysis of respiratory burst activity in phagoxytes with hydroethidine and 2/7'-dichlorofluorescin. J. Leukoc. Biol. 47 $440-448$

36. Carter WO, Narayanan PK and Robinson JP (1994) Intracellular hydrogen peroxide and superoxide anion detection in endothelial cells. J. Leukoc. Biol. 55: 253-258

37. Giandomenico AR, Cerniglia GE, Biaglow JE, Stevens CW and Koch CJ (1997) The importance of sodium pyruvate in assessing damage produced by hydrogen peroxide. Free Radic. Biol. Med. 23: 426-434

38. Suzuki A, Iwasaki M and Wagai N (1997) Involvement of cytoplasmic serine protease and CPP32 subfamily in the molecular machinery of caspase 3 activation during Fas-mediated apoptosis. Exp. Cell Res. 233: 48-55

39. Han Z, Hendrickson EA, Bremner TA and Wyche JH (1997) A sequential twostep mechanism for the production of the mature p17:p12 form of caspase-3 in vitro. J. Biol. Chem. 272: 13432-13436

40. Tang D and Kidd VJ (1998) Cleavage of DFF-45/ICAD by multiple caspases is essential for its function during apoptosis. J. Biol. Chem. 273: 28549-28552

41. Liu X, Zou H, Slaughter C and Wang X (1997) DFF, a heterodimeric protein that functions downstream of caspase-3 to trigger DNA fragmentation during apoptosis. Cell 89: 175-184

42. Crompton $M$ (1999) The mitochondrial permeability transition pore and its role in cell death. Biochem. J. 341: 233-249

43. Zamzami N, Marchetti P, Castedo M, Zanin C, Vayssiere J-L, Petit PX and Kroemer G (1995) Reduction in mitochondrial potential constitutes an early irreversible step of programmed cell death in vivo. J. Exp. Med. 181: 1661 - 1672

44. Kroemer G, Petit P, Zamzami N, Vayssiere J-L and Mignotte B (1995) The biochemistry of programmed cell death. FASEB J. 9: 1277-1287
45. Marzo I, Brenner C, Zamzami N, Jurgensmeir JM, Susin SA, Vieira HLA, Prevost M-C, Xie Z, Matsuyama S, Reed JC and Kroemer G (1998) Bax and adenine nucleotide translocator cooperate in the mitochondrial control of apoptosis. Science 281: 2027-2031

46. Kantrow SP and Piantodosi CA (1997) Release of cytochrome c from liver mitochondria during permeability transition. Biochem. Biophys. Res. Comm. 232: $669-671$

47. Ellerby HM, Martin SJ, Ellerby LM, Naien SS, Rabizadeh S, Salvesen GS, Casiano CA, Cashman NR, Green DR and Bredesen DE (1997) Establishment of a cell-free system of neuronal apoptosis: comparison of premitochondrial, mitochondrial and postmitochondrial phases. J. Neurosci. 17: 6165-6178

48. Marzo I, Brenner C, Zamzami N, Susin SA, Beutner G, Brdiczka D, Remy R, Xie Z-H, Reed JC and Kroemer G (1998) The permeability transition pore complex: A target for apoptosis regulation by caspases and Bcl-2-related proteins. J. Exp. Med. 187: 1261-1271

49. Zamzami N, Susin SA, Marchetti P, Hirsch T, Gomez-Monterrey I, Castedo Mand Kroemer G (1996) Mitochondrial control of nuclear apoptosis. J. Exp. Med. 183: $1533-1544$

50. Yang X, Chang HY and Baltimore D (1998) Autoproteolytic activation of procaspases by oligomerization. Mol. Cell $1: 319-325$

51. Hakem R, Hakem A, Duncan GS, Henderson JT, Woo M, Soengas MS, Elia M, de la Pompa JL, Kagi D, Khoo W, Potter J, Yosida R, Kaufman SA, Lowe SW, Penninger JM and Mak TW (1998) Differential requirement for caspase 9 in apoptotic pathway in vivo. Cell 94: 339-352

52. Thornberry NA, Rano TA, Peterson EP, Rasper DM, Timkey T, Garcia-Calvo M, Houtzager VM, Nordstrom PA, Roy S, Vaillancourt JP, Chapman KT and Nicholson DW (1997) A combinatorial approach defines specificities of members of the caspase family and granzyme B. J. Biol. Chem. 272: 17907-17911

53. Ramakrishnan N and Catravas GN (1992) N-(2-mercaptoethyl)-1,3-propanediamine (WR-1065) protects thymocytes from programed cell death. J. Immunol. 148: $1817-1821$

54. Kim JH, Lee EJ, Hyun JW, Kim SH, Mar W and Kim JK (1998) Reduction of radiation-induced chromosome aberration and apoptosis by dithiothreitol. Arch. Pharm. Res. 21: 683-687

55. Bustamante J, Slater AFG and Orrenius S (1995) Antioxidant inhibition of thymocyte apoptosis by dihydrolipoic acid. Free Radic. Biol. Med. 19: 339-347

56. Talley AK, Dewhurst S, Perry SW, Dollard SC, Gummuluru S, Fine SM, New D, Epstein LG, Gendelman HE and Gelbard HA (1995) Tumornecrosis factor alphainduced apoptosis in human neuronal cells: Protection by the antioxidant $\mathrm{N}$ acetylcysteine and the genes $b c l-2$ and crmA. Mol. Cell. Biol. 15: 2359-2366

57. Gurr J-R, Bau S-T, Liu F, Lynn S and Jan K-Y (1999) Dithiothreitol enhances arsenic trioxide-induced apoptosis in NB4 cells. Mol. Pharmacol. 56: 102-109

58. Held KD, Tuttle SW and Biaglow JE (1993) Role of the pentose cycle in the oxygen radical-mediated toxicity of the thiol-containing radioprotector dithiothreitol in mammalian cells. Radiat. Res. 134: 383-389

59. Lennon SV, Martin SJ and Cotter TG (1991) Dose-dependent induction of apoptosis in human tumour cell lines by widely diverging stimuli. Cell Prolif. 24: 203-214

60. Deveraux QL and Reed JC (1999) IAP family proteins - suppressors of apoptosis. Genes Dev. 13: 239-252

61. Hopcia KL, McCarey YL, Sylvester FC and Held KD (1996) Radiation-induced apoptosis in HL60 cells: Oxygen effect, relationship between apoptosis and loss of clonogenicity, and dependence of time to apoptosis on radiation dose. Radiat. Res. 145: 315-323

62. Sellins KS and Cohen JJ (1987) Gene induction by $\gamma$-irradiation leads to DNA fragmentation in lymphocytes. J. Immunol. 139: 3199-3206 